\title{
Primary systemic amyloidosis
}

INSERM

\section{Source}

INSERM. (1999). Orphanet: an online rare disease and orphan drug data base. Primary systemic amyloidosis. ORPHA:314701

Primary systemic amyloidosis (PSA) is a form of AL amyloidosis (see this term) caused by the aggregation and deposition of insoluble amyloid fibrils derived from misfolded monoclonal immunog lobulin light chains usually produced by a plasma cell tumor (see this term) and characterized by multiple organ involvement. 